\title{
Onion (Allium Cepa) Production in Urban and Peri-Urban Areas: Financial Performance and Importance of This Activity for Market Gardeners in Southern Benin
}

\author{
Fabrice Dossa $^{1 *}$, Yann Miassi ${ }^{1}$ and Kémal Banzou ${ }^{2}$ \\ ${ }^{1}$ Department of Economics and Rural Sociology, University of Parakou, Benin \\ ${ }^{2}$ Department of Plant Production, Catholic University of West Africa, Benin
}

Received: 眥 June 13, 2018; Published: 非 June 22, 2018

*Corresponding author: Fabrice Dossa, Department of Economics and Rural Sociology, Faculty of Agriculture, University of Parakou, BP 123, Parakou, Benin

\begin{abstract}
Food safety has always been and continues to be a major concern for all countries of the world. This concern is all the more perennial in the developing countries like Benin with a low economic level and still rudimentary and extensive agriculture. To reduce a little bit of food insufficiency, is developed urban and peri-urban agriculture based mainly on market gardening. This study focused particularly on the production of onion in southern Benin. It aims to analyze its performance, to understand the importance of this activity but also to see what are the obstacles faced by these producers. Three municipalities were investigated: Grand-Popo, Cotonou and Sèmè-Kpodji. A total of 60 farmers were surveyed at 20 per municipality. Quantitative and qualitative tools were combined for the analysis of data collected through individual and group interviews. A joint analysis approach was used to achieve specific objectives. It consists to combine speech analysis, participant observation with statistical tools such as the frequency distribution, the regression model and calculation of performance indicators. It follows from all of these analyzes that onion production is profitable from a financial point of view. This performance is enhanced by factors such as age, experience and membership of a producer group. Similarly, the farmers claimed for majority that onion occupies a special place in their market garden production. This production improves their socio-economic and food situations. However, the constraints that undermine the more onion production and thus constitute important producer concerns are financial, institutional, organizational, property constraints and those directly related to production. Farmers therefore, expect a little more effort from agricultural policies to improve the development of this sector.
\end{abstract}

Keywords: Onion; Performance; Importance; Barriers; Southern Benin

\section{Introduction}

The agricultural sector provides essentially food security and livelihood in Benin, with $70 \%$ of the population earning their income from agriculture [1]. This sector is even more important for developing countries like Benin, where it is one of the pillars of the economy [2]. Nowadays, it is increasingly recognized that in the developing world, nearly three billion people live on less than US $\$ 2$ per day [3]. Majority of this population are smallholder farmers producing staple food crops with little prospects of generating higher incomes. Hence, diversification into high-value horticulture is essential for increasing farm incomes, alleviating poverty and improving livelihoods [4,5]. Globally, food production is still a challenge $[6,7]$, especially with the projected rise in world population to over 9 billion by 2050 and increased urbanization in cities [8]. There is therefore still some justification for increasing agricultural production in the coming years $[9,10]$. Urban vegetable production is an intensive agricultural strategy through which urban dwellers secure income and improve their livelihoods [11]. 
Urban and periurban agriculture (UPA) has been defined differently by Mougeot [12,13], Moustier [14], and Van Veenhuizen [15], but they all lay stress on agriculture's relationship with the city as a resource and destination for outputs [16].

Onion (Allium cepa L.) is one of the most important commercial spice crops of the world belongs to Amaryllidaceae family [17]. Moreover, essential oil and sulfur compounds have been found in onion which is responsible for unique odour, flavour, and taste [18]. Based on the interested situation in health food development, the properties of onion and its extract as a functional agent have been demonstrated in many previously [19]. Onion (Allium cepa L.) has been valued as food and medicinal plant since ancient times [20]. It is widely cultivated secondly to tomato, and is a vegetable bulb crop known to most cultures and consumed worldwide [21]. The major onion producing countries of the world are China, India, USA, Turkey, Japan, Spain, Brazil, Poland and Egypt [22]. In Benin West African country, this culture has become very important especially in urban areas where the market gardeners devote more land to the production of onion. It is in order to make an inventory and understand onion production in southern Benin that this study was conducted. Specifically, the study aims to analyze firstly the profitability of onion production, secondly to appreciate the importance of onion production in southern Benin and ending by identifying the difficulties facing the farmers.

\section{Materials and Methods}

\section{Study zone}

The municipalities of Grand-Popo, Sèmè-Kpodji and Cotonou are located in south of Benin and cover respectively $289 \mathrm{~km}^{2}, 250 \mathrm{~km}^{2}$ to $79 \mathrm{~km}^{2}$. The town of Grand Popo is located in the southwestern department of Mono. It is limited to the north by the Athiémé, Comé and Houéyogbé communes, south by the Atlantic sea, to the southwest by the communes of Ouidah and Kpomassè and west by Table 1: Composition of the sample per commune.

\begin{tabular}{|c|c|c|c|c|}
\hline Communes & Grand-Popo & Sèmè-Kpodji & Cotonou & Total \\
\hline Number of farmers & 20 & 20 & 20 & 60 \\
\hline
\end{tabular}

Source: Results of investigation, 2018.

\section{Data analysis}

In this study, the performance of onion production in southern Benin was assessed using several indicators of financial performance. To this end, it is inspired by the work of Dédéwanou [23]. Several profitability indicators were therefore calculated, namely: Gross Product Value (PBV), Added Value (VA), the Gross Operating Income (RBE) and Net Operating Income (RNE). From Adégbola [24] and Bockel [25] studies, these indicators can be calculated as follows:

a) Product Gross Value (PBV): Denoting by Q the quantity of onion obtained and PU the selling price of the kilogram, the Gross Product Value (PBV) is given by: $\mathrm{PBV}=\mathrm{Q}^{*} \mathrm{PU}$. the Republic of Togo. Located between the parallel $6^{\circ} 22^{\prime}$ and $6^{\circ} 28^{\prime}$ north latitude and the meridian $2^{\circ} 28$ 'and $2^{\circ} 43^{\prime}$ east longitude, the commune of Sèmè-Kpodji is in the Department of Ouémé, the Southeast of the Republic of Benin on the Atlantic coast. It is limited to the north by the city of Porto Novo and Aguégué, south by the Atlantic sea, to the east by the Federal Republic of Nigeria and to the west by the city of Cotonou. The town of Cotonou in turn is located on the barrier beach that stretches between Nokoué Lake and the Atlantic sea, consistitued of alluvial sands of about five meters maximum height. It represents the only municipality in the Littoral department is bounded to the north by the municipality of Sô-Ava and Nokoué Lake, south by the Atlantic sea, to the east by the town of Seme-Kpodji and West by that of Abomey-Calavi. These towns are from a set that has a sub-equatorial climate except Sèmè-Kpodji bathed in a Guinean Sudanese climate. We find in these areas, the sandy type of soil, leached and hydromorphic. The municipalities of Grand-Popo, Sèmè-Kpodji and Cotonou have various socio-cultural group included the mina, the Goun, the Xwla and Toffins.

\section{Methodology}

To conduct this research, three (03) municipalities were selected in southern Benin. These towns were chosen partly because of their significant contribution to the onion production of the department to which they belong, and secondly because of the large number of onion producers they contain. We have Grandpopo, Sèmè-Kpodji and Cotonou. Therefore, (60) producers made object of investigation at the rate of twenty (20) producers per commune. This sample consists only of onion producers. Note that the sample was achieved in a simple random in order to give all producers the same probability of being selected. Table 1 show the composition of the sample per commune: The collected data is related not only to the characteristics of the producers, but also to expenditure and revenue of producers. The information has been collected on the basis of a questionnaire and a pre-prepared interview guide. 
e) Gross Operating Income (RBE): It is given by the formula: $\mathrm{RBE}=\mathrm{VA}$-(Labor compensation + financial expenses + taxes). To estimate the RBE, it was considered only the hired labor.

f) Net Operating Income (RNE) This indicator represents the balance of RBE less the value of depreciation. Its formula is given by: RNE=RBE-Amortization.

g) The RNE expresses the gain (or loss) Economic agent once acquitted all current operating expenses. RNE, expresses the economic gain (or loss) given the investments made previously. Therefore RNE is obtained by deducting from the PBV all expenses related to production.

h) This study is also proposed to analyze the determinants of the profitability of onion production. For this purpose this study was based on the work of Tovignan [26] and Allagbe [27]. A multiple linear regression model has been developed on the basis of sixty (60) onion producers. Thus, the multiple linear regression formula can be written as follow:

$$
y=\alpha_{0}+\alpha_{1} x_{i}+\varepsilon_{i}
$$

Where: $y$ is the dependent variable, $x i$ the explanatory variables, $\alpha$ is a constant called "intercept" and Ei the error term of the model.

The evaluation of the importance of onion production consists to determine changes in socio-economic and food orders induced by this production in the three investigated municipalities. To do this, in a collection of producer's speeches about perceived improvements since they produce onion was done. The analysis fundamentally was based on the discourse of these producers and through participant observation. More simply, the analysis consists to explain the effects induced by the production of onion in a social context through producer's speeches and participant observation. These explanations were supported by the comments of some significant producers. The frequency distribution and the farmer's speeches allowed identifying the barriers of onion production in the study areas.

\section{Presentation of the variables included in the model}

Two types of variables are included in the regression model turned. We have on the one hand, the dependent variable and the other explanatory variables. The dependent variable is the Net Operating Income of producers. It was therefore question of identified and analyzed the factors influencing the income of onion producers. So many variables called " explanatory "were introduced in the regression model. The explanatory variables included in the model are: age of the producer (Age), household size (Mena), the number of agricultural household assets (ActifM), the level of literacy (Alpha), educational level (Inst), seniority (Anc), membership of a group (APPG), the cultivated area (Sup), the mode of land access (ACCT) and fixed costs (CF).

There are a lot of reasons for the incorporation of these variables in the regression model. a) Age: Age is a variable expressed in years. Several studies identify age as a parameter determining the profitability of agricultural production. Indeed, the more the producer is aged, the more he gains experience enabling him to improve the financial performance of its operations. This variable has been introduced into the model to see if it has an influence on the net income of onion producers in South Benin. The age would have a positive effect on the financial performance of onion production.

b) Mena: This variable refers to the number of persons who form the household of the producer. Household size is a potential source of labor and allows producers to increase production. It therefore positively influences the net income of the onion producer.

c) ActfM: This variable represents the number of agricultural workers of producer household. The number of assets would have a positive effect on the profitability of production because the market garden production, especially onions requires a lot of labor.

d) Alpha and Inst: Education can acquire a base regarding the management of a exploitation. So, educated onion producers will have a higher income than their uneducated counterparts. The effect of literacy and education on the net income would be positive.

e) Old: This is the number of the producer seniority year. Over the producer has a number of high year of seniority, the more he has strengths and knowledge that will enable him to improve his onion production. It therefore positively influences the net income of the onion producer.

f) APPG: This variable represents the membership or not of the producer to a group. It is a binary variable taking the values 1 if the producer is a member of an onion producer group or 0 if not. This variable could have a positive effect on financial performance of the production, in the sense that the producer's group members have the support of extension services as well as that of some development programs and projects in order to improve their performance.

g) Sup: The area planted is a continuous variable that can influence the profit of the producer. Thus, onion producers who planted large areas, have a higher net income than those who planted a small area. The effect of the wheat area on net income of the producer would be positive.

h) ACCT: This variable represents the farmer's access mode to the ground. This variable is set to 0 if the producer has access to land by inheritance; 1 if access rental. The fact that the onion producer owns the piece of land to his work, it could have an influence on his income because the latter will invest the necessary capital. A positive or negative sign of the coefficient for this variable would be expected.

i) CF: Fixed costs represent costs of production. Over were these expenses less producers take advantage of his farm. These variables will therefore have a negative effect on net income of onion producers. 
Table 2: Summary of the model variables and the expected signs.

\begin{tabular}{|c|c|c|c|}
\hline Variables & Variable types & \multicolumn{2}{|l|}{ Description } \\
\hline \multicolumn{4}{|c|}{ Explained variable } \\
\hline Net Operating Income (RNE) & Quantitative & Dependent Variable: Net Operating Income Value & \\
\hline \multicolumn{3}{|c|}{ Explanatory variables } & Sign expected+ \\
\hline Age & Quantitative & Years of the farmer & \\
\hline Household size & Quantitative & Number of people who form the household & + \\
\hline Number of active Farm household & Quantitative & Number of agricultural household assets & + \\
\hline Level literacy & Qualitative & $\begin{array}{c}\text { Level of literacy. This variable is set to } 0 \text { when the producer can neither } \\
\text { read nor write in the local language; } 1 \text { when he knows only read and } 2 \\
\text { when literate. }\end{array}$ & + \\
\hline Level of education & Qualitative & $\begin{array}{l}\text { Producer education level. This variable is set to } 0 \text { when the farmer has } \\
\text { no education; } 1 \text { to the primary level; } 2 \text { for the secondary level, or } 3 \text { for } \\
\text { university }\end{array}$ & + \\
\hline Seniority & Quantitative & Number of years of seniority & + \\
\hline Access to land & Qualitative & $\begin{array}{l}\text { Mode of access to land. This variable takes } 0 \text { if the producer has access to } \\
\text { land by inheritance; or } 1 \text { if there is access by rental }\end{array}$ & $+/-$ \\
\hline Belonging to a group & Qualitative & Member or not of a group. This variable is set to 0 otherwise; or 1 if yes. & + \\
\hline area sown & Quantitative & Area sown by the respondent & + \\
\hline Fixed charges & Quantitative & Fixed costs related to the production & - \\
\hline
\end{tabular}

Source: Results of literature searches, 2018.

Table 2 shows a summary of all the variables included in the model with their expected signs. Note that two software's were used in this section. SPSS has achieved descriptive statistics and STATA software was used to perform econometric regression.

\section{Results and Discussion}

\section{A zoom on onion production and consumption}

Table 3: The ten largest producers of onion in the world.

\begin{tabular}{|c|c|c|}
\hline Rank & Country & Total production (tonnes) \\
\hline 1 & China & $2,05,07,759$ \\
\hline 2 & India & $1,33,72,100$ \\
\hline 3 & USA & $33,20,870$ \\
\hline 4 & Egypt & $22,08,080$ \\
\hline 5 & Iran & $19,22,970$ \\
\hline 6 & Turkey & $19,00,000$ \\
\hline 7 & Pakistan & $17,01,100$ \\
\hline 8 & Brazil & $15,56,000$ \\
\hline 9 & Russia & $15,36,300$ \\
\hline 10 & Republic of Korea & $14,11,650$ \\
\hline
\end{tabular}

\section{Source: FAO, 201221.}

The following Table 3 shows the countries that produce most of onion in the world. China and India are the primary onion growing countries, followed by the USA, Egypt, Iran, Turkey, Pakistan, Brazil, the Russian Federation, and the Republic of Korea [21]. Onion productivity is highest in the Republic of Korea (66.16t/ ha), followed by the USA (56.26t/ha), Spain (53.31t/ha), and the Netherlands (51.64t/ha). With world production of $74,250,809$ tonnes from an area of 4,364,000 hectare, the average productivity across the world is 19.79 t/ha. The international trade in onion exports is 6.77 million tonnes. The Netherlands is the highest onion exporter (1.33 million tonnes) followed by India, China, Egypt, Mexico, USA, Spain, and Argentina. Bangladesh, Malaysia, the Russian Federation, the UK, Japan, and Saudi Arabia are the major onion importing countries in the world [21]. According to Bethesda [28], West Africa represents less than $2 \%$ of the world output of onion. However, it represents $10 \pm 25 \%$ of the vegetables consumption in West Africa: its culture is ancient in the region and extends through several agro-ecological zones, ranging from arid Sahelian countries to humid coastal countries [29]. In Benin particularly, the production of the onion is relatively young (40-50 years) [30].

If there is no recent and clear statistics of the volume of domestic onion production, it should be noted that the production has been in galloping development of around 70,000 tonnes against 15,000 just 20 years ago. According to Baco [31] and Affomasse [32], the average area of onion production is 1 ha in Benin representing $57 \%$ of total area under vegetable crops. Onion is the market garden predominant crop in Benin since it is grown by more than $80 \%$ of vegetable growers. Similarly, the onion is a product consumed by 
all the urban and rural beninese. Urban consumption is estimated at $3.3 \mathrm{~kg}$ of onions per year per person. This demand represents a commercial demand for 7000 tonnes per year. The consumption of rural populations against is estimated at $1.1 \mathrm{~kg}$ of onions per year per person, a rural consumption of about 14000 tonnes. Although the production of onion is growing, the country is unable to meet domestic demand of around 45,000 tonnes [33] throughout the year, which explains the need to import the remaining, mainly by Niger, Gaya-Malanville border [34].

\section{Source of supply and sector's actors}

Niger, Burkina Faso, Nigeria and Benin are the biggest onion supply sources to West African consumers. Niger is the largest producer and exporter of onion in West Africa and its commercial network allows to supply the major coastal markets of the sub region. In Benin, for against the import of this speculation is more important because domestic production cannot meet the needs of people. However, nationally the most productive zones are Malanville, Karimama and Grand-Popo followed by large cities (Cotonou, Sèmè-Kpodji, Ouidah, Dassa and Glazoué) that also produce a considerable quantity of onion as urban or suburban vegetable. The production of onion, like most agricultural crops

Table 4: selling price of $100 \mathrm{~kg}$ bag of cultivated varieties of onion.

\begin{tabular}{|c|c|c|c|c|}
\hline \multicolumn{2}{|c|}{ Onion Varieties } & Red Galmi & White Galmi & Dendi \\
\hline \multirow{2}{*}{ Bag price } & Period of abundance (CFA) & 14500 & 19500 & 16000 \\
\cline { 2 - 5 } & Period of high cost (CFA) & 50000 & 75000 & 60000 \\
\hline
\end{tabular}

Source: Results of investigation, 2018.

\section{The actors in the Value Chain (VC): a multitude of stakeholders}

The onion sector is composed of a large number of actors can be subdivided into four groups. It is the operators of the value chain; supporters of the chain; institutional actors; stakeholders and external facilitators.

a) The operators of the value chain are most concerned. They are upstream of the value chain and are for the most part the first owners of the product. They represent producers, sellers or resellers, customers or buyers, processors, intermediaries, wholesalers and retailers.

b) The supporters of the chain are those that are not directly related to the process of production or marketing. They are actors who sell their services to producers, processors and traders. This is usually suppliers of inputs (seeds, fertilizers, pesticides), moneylenders or credit providers, pumps sellers and gasoline retailers, MFIs, intermediaries, carriers, of agricultural laborers, carters to transport the onion over a short distance etc.

c) Institutional actors are the actor's group that provides institutional support in the context of a continuous improvement and regulation of the sector activities. These include state in Benin knows two periods: a period of abundance (January to May) characterized by high availability of onions on the market. Currently, importers of other countries (Nigeria, Burkina Faso, Nigeria) are sourcing local onion to neighboring countries. The second period, that of solder (August to December) is characterized by the scarcity of onions and increasing the product price on the market. In Benin, onion varieties are encountered onion Galmi (or white Galmi onion), purple Galmi (or onion Agades) and Dendi onion of Malanville (red onion or local onion). Of these varieties, the white Galmi remains the favorite onion for Beninese consumers. Besides his characteristics that one knows (bigger than the red onion, relatively smooth, easier to maintain, less spicy (less acidic)), it is its organoleptic qualities that are most appreciated (the pleasant flavor that it gives to the sauce and the fact that it does not blacken). Regarding the sale price of onions, it knows a big fluctuation depending on the period as specified above. Thus, the bag of $100 \mathrm{~kg}$ of acceptable quality onion (red onion Galmi) and the most appreciated (white Galmi onion) respectively cost 14,500 CFA and 19,500 CFA in times of plenty against respectively 50,000 CFA and 75.000 CFA in lean period. Table 4 shows the selling price of $100 \mathrm{~kg}$ bag of different onion varieties in the study area. structures (MAEP, CECPA, SCDA, customary chiefs, customs, police, gendarmerie, research and extension services etc.). The finding done is that these groups of actors do not really invest in the development of the sector.

d) Stakeholders and external facilitators are actors who aim to improve the socio-economic life of rural populations. They provide financial and technical support primarily to producers. These are NGOs, development projects and programs, and specific fund donors.

Downstream of the chain, there is a last group of actors which is relatively large: The consumers. Onion Consumers can be at any level of the chain. He may be the producer and in this case he practices subsistence farming or firm that process onion for example. It is important to note that in this sector, the actors play complementary roles. The value chain would not be good if each group of actors not playing its role effectively. The following Figure 1 shows schematically the various actors in the onion value chain in Southern Benin: In fact, some of the onions harvested by farmers are sold to rural collectors or directly to local markets. Intermediaries and wholesalers, for their part, buy onion for the most part from rural collectors or local markets. The purchased stock is then transported to urban markets (for example the Dantokpa, 
Malanville and Parakou markets). However, it should be noted that some producers sell their crops directly in these urban markets. The following circuit (Figure 2) shows the onion commercialization process described by respondent's producers. All actors in the chain are present and the complementary relationship they have in the onion value chain.

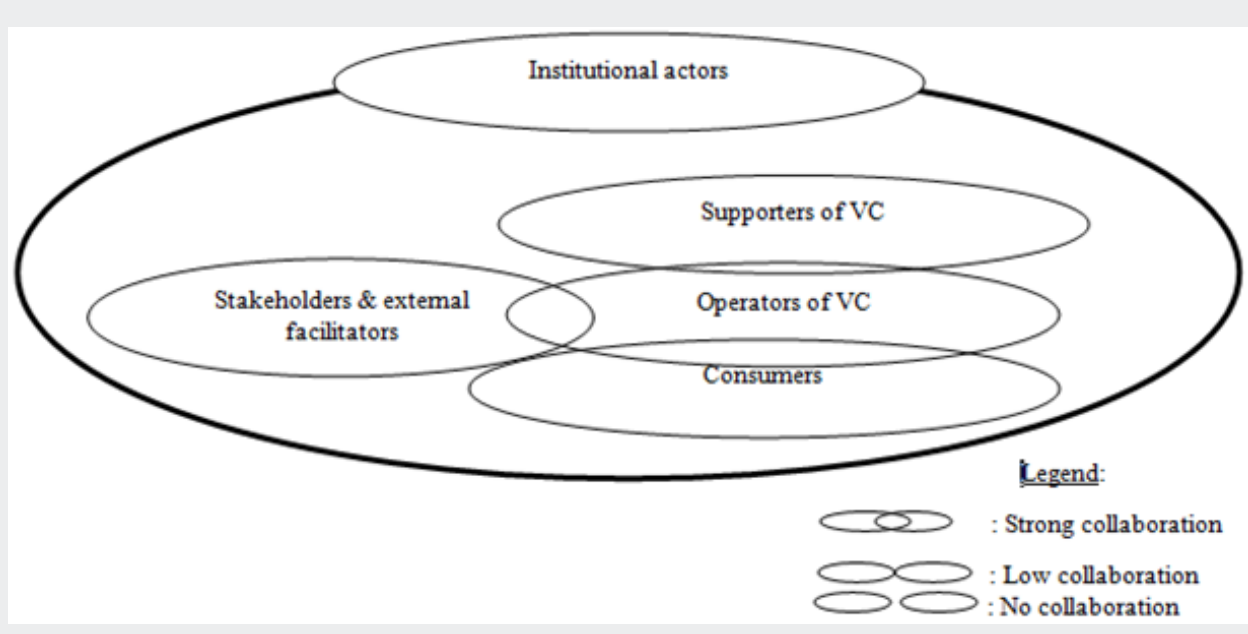

Figure 1: Groups of actors in the Onion value chain in Benin.

Source: Results of investigation, 2018.

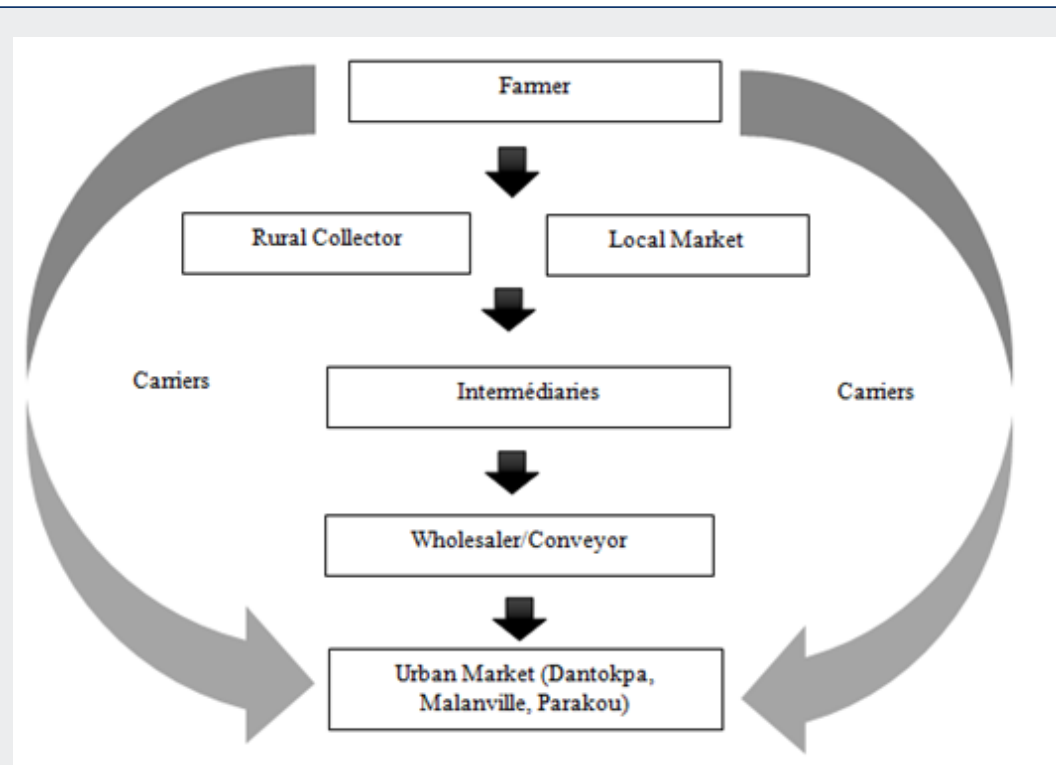

Figure 2: Process of marketing of onion value chain.

Source: Results of investigation, 2018.

\section{Potential and motivations of onion producers}

The onion production in both North and South Benin is favored by some natural assets available in the country. It is:

a) Agro-ecological potential of Benin (soils, climate, topography, vegetation, drainage network).

b) The geographical location of Benin (proximity to other producing countries such as Niger, Nigeria, Burkina Faso and other countries onion importers like Togo).

In addition to the natural potential, certain provisions promote onion production in Benin. We can talk about: a) Mechanized irrigation through pumps for irrigation, from the shallow groundwater.

b) Interventions of many projects to support the intensification and promotion of fruit and vegetable crops.

c) Applied search to identify ways of improving vegetable production.

d) The producer's enthusiasm for onion cultivation due to its high profitability.

e) The supply in specific inputs (Improved seeds, products pesticides, fertilizers...) from the 2000s. 
f) Existence of market garders communal groups.

g) The existence of an international market and many village markets.

Especially for urban producers surveyed (Cotonou, SemeKpodji and Grand Popo) these are the following benefits that motivate these market gardeners to engage in the cultivation of onion.

a) The high financial profitability of onion production

b) More favorable conditions for the intensification of production systems, due to land pressure and pluriactivity that promote the enhancement of complementarities.

c) The geographical proximity to markets (Dantokpa market for example) reduces transportation costs compared to remote rural areas.

d) The reduction of energy and time in getting goods to consumers: transport, storage, especially for fresh produce.

e) The reduction of post-harvest losses due to the proximity of production areas.

Table 5: Statistical variables characterizing respondents.

\begin{tabular}{|c|c|c|}
\hline Variables & Average & Standard Deviation \\
\hline \multicolumn{3}{|c|}{ Quantitative Variables } \\
\hline Age (Years) & 28.07 & 7.71 \\
\hline Size Of Households & 4.27 & 2.2 \\
\hline Number Of Agricultural Workers & 2.97 & 1.34 \\
\hline Age (Years) & 5.83 & 3.85 \\
\hline Wheat Area $\left(\mathrm{m}^{2}\right)$ & 2785.48 & 2995.17 \\
\hline Variable Loads $\left(\mathrm{Cfa} / \mathrm{m}^{2}\right)$ & 92.82 & 61.11 \\
\hline Fixed Costs $\left(\mathrm{Cfa} / \mathrm{m}^{2}\right)$ & 5.76 & 5.32 \\
\hline \multicolumn{3}{|c|}{ Qualitative Variables } \\
\hline \multirow{2}{*}{ Gender (\%) } & Man & 78.3 \\
\hline & Wife & 21.7 \\
\hline \multirow{2}{*}{ Belonging To A Group (\%) } & Yes & 50 \\
\hline & No & 50 \\
\hline \multirow{2}{*}{ Access To Land (\%) } & Leasing & 38.3 \\
\hline & Heritage & 61.7 \\
\hline \multirow{3}{*}{ Level Literacy (\%) } & Read Or Write & 18.3 \\
\hline & Read Only & 25 \\
\hline & Read And Write & 56.7 \\
\hline \multirow{4}{*}{ Education Level (\%) } & No & 8.3 \\
\hline & Primary & 53.3 \\
\hline & Secondary & 23.4 \\
\hline & University & 15 \\
\hline
\end{tabular}

Source: Results of investigation, 2018.

\section{Better product quality in terms of freshness for perishable . \\ Socioeconomic and demographic characteristics of the}

In southern Benin, specifically in the municipalities of Grand-Popo, Sèmè-Kpodji, and Cotonou onion production is predominantly male $(78.3 \%$ of men against $21.7 \%$ of women). These producers have an average age of $28( \pm 08)$ with a tenure of 06 years $( \pm 04)$. Moreover, in the study area average household has 04 persons $( \pm 02)$ and $03( \pm 01)$ agricultural assets. Levels of literacy and education of the surveyed producers are more or less acceptable in public Grand-Popo, Sèmè-Kpodji and Cotonou. Note also that $50 \%$ of producers are active members of a group against a second half not belonging to a producer group. Overall, there are $81.7 \%$ literate farmers and $91.7 \%$ educated farmers. In the study zone, onion producers have an average area under crop of 2785.48 $\mathrm{m}^{2}$. These areas are obtained either legacy $(61.7 \%)$ or rent $(38.3 \%)$. To operate their farms, producers face two types of loads in their exploitations. These called "variables" and those "fixed". These charges are respectively $93 \mathrm{CFA} / \mathrm{m}^{2}$ and $5.76 \mathrm{CFA} / \mathrm{m}^{2}$. Table 5 shows the statistical variables characterizing respondents. 


\section{Financial Performance of onion production}

To assess the financial performance of onion production, analysis of operating farmers account was made. Thus, the results of the analysis reported in Table 4 shows that onion production is profitable in southern Benin as the average Net Operating Income calculated is positive ( $689 \mathrm{CFA} / \mathrm{m} 2>0)$. These results are consistent with those of MAHRH [35] and Fanou [36] whose studies finally led to the conclusion that onion production is profitable. Table 6 below shows the operating account of onion producers. Note that the financial performance indicators used were calculated in $\mathrm{CFA} / \mathrm{m}^{2}$.

Table 6: Financial performance indicators calculated.

\begin{tabular}{|c|c|}
\hline Parameter $\left(\mathbf{C F A} / \mathbf{m}^{\mathbf{2}}\right.$ ) & Average \\
\hline Product Brute Value & 787 \\
\hline Intermediate consumption (Fertilizer, foliar \\
fertilizer) & 72 \\
\hline Added Value & 715 \\
\hline Cost of labor & 21 \\
\hline Other financial expenses (storage, fee, land rent) & 2 \\
\hline Gross Operating Income & 692 \\
\hline technical amortization & 3 \\
\hline Net Operating Income & 689 \\
\hline
\end{tabular}

Source: Results of investigation, 2018.

\section{Determinants of onion production profitability}

The multiple linear regression model performed to identify the determinants of the onion production profitability is generally significant at the $1 \%$ level $(\mathrm{p}=0.0000<1 \%)$. Variables such as age of the producer, the cultivated area, the level of literacy, membership in a group, the experience, and fixed costs are those which influence the onion production profitability in southern Benin. The variables of the model that are not significant are: household size, the number of farm assets, access to land and the level of producer instruction. Age has a positive significant effect on the threshold of $1 \%$ on the profitability of onion production. We therefore deduce that more the producer is old, more sometimes he took advantage of its business. The producer thus gains experience with time. Which experience allows him to improve the financial performance of his exploitations? However, these producers are very few open to new technologies that are proposed to improve their income. They therefore remain conservative. This conclusion stems from the fact that seniority has a negative significant effect on the threshold of $1 \%$ on the profitability of onion production. It is the same for literacy that has a negative and significant effect on the threshold of $1 \%$ on the profitability of onion production in southern Benin. These results are contrary to those obtained by Labiyi [37] which identify education as a determinant of economic efficiency of resource allocation in soybean production in Benin. Membership of the producer group has a positive and significant effect at the $10 \%$ threshold on the profitability of onion production.

Thus, onion producers who are members of a group have higher net profits than the others because they will benefit from certain advantages. We can highlight the sharing of information, mutual assistance and the expertise that a producer can take the other being a member of an onion producer group. These results are consistent with those of Tovignan [26] who found that producers who are members of a group have a higher net profit than others who do not belong to any group. Unlike the membership of a producer group, the wheat area has a negative and significant effect on the threshold $5 \%$ on the profitability of his exploitations. Thus, over the cultivated area, the less the onion producer benefits from his activities. The producers do not manage to meet the obligations belong to large farms. Note that these results contradict those obtained by Tovignan [26] who deduced that producers who have a large area under cotton production have a higher net profit than those having a small area. It is the same for the fixed charges that have a negative effect and significant at the $5 \%$ level on the profitability of the production of onion. Therefore, the more these expenses amounted less the producer benefits from his plantation. Table 7 shows the results of estimation of multiple linear regression model performed.

Table 7: Estimated multiple linear regression models.

\begin{tabular}{|c|c|c|c|c|}
\hline Net operating income & Coefficient & Standard error & $\mathbf{t}$ & prob \\
\hline Constant & $487.9092 * * *$ & 84.2756 & 5.79 & 0,000 \\
\hline Age & $14.6900^{* * *}$ & 3.1459 & 4.67 & 0,000 \\
\hline Household size & -16.3955 & 10.6268 & -1.54 & 0.129 \\
\hline Number of farm assets & 24.862 & 17.52671 & 1.42 & 0.162 \\
\hline Literacy level & $-43.1736^{* * *}$ & 15.3434 & -2.81 & 0,007 \\
\hline Level of education & 13.6807 & 14.4876 & 0.94 & 0,350 \\
\hline Seniority & $-20.1665^{* * *}$ & 6.1295 & -3.29 & 0,002 \\
\hline \multirow{2}{*}{ Belonging to a group area sown } & $52.3704^{*}$ & 26.9939 & 1.94 & 0.058 \\
\hline & $-0.1036^{* *}$ & 0.0047 & -2.2 & 0.033 \\
\hline
\end{tabular}




\begin{tabular}{|c|c|c|c|c|}
\hline Access to land & -37.012 & 25.8671 & -1.43 & 0,159 \\
\hline Fixed charges & $-7.0954 * *$ & 2.7258 & -2.6 & 0.012 \\
\hline \multirow{5}{*}{ Linear regression } & \multicolumn{4}{|c|}{ Number of observation $=60$} \\
\hline & \multicolumn{4}{|c|}{$F(10,49)=6.78$} \\
\hline & \multicolumn{4}{|c|}{ Prob $>\mathrm{F}=0.0000 * * *$} \\
\hline & \multicolumn{4}{|c|}{ R-squared $=0.5805 \mathrm{Adj}$} \\
\hline & \multicolumn{4}{|c|}{ R-squared $=0.4949$} \\
\hline
\end{tabular}

*** = Significant at $1 \% ; * *=$ significant at $5 \% ; *$ Significant at $10 \%$

Source: Estimation Results, 2018.

\section{Importance of onion production in south of benin}

Onion importance for farmers: The onion producers constitute the largest actors group in the in the sector. Therefore, this production contributes to job creation for over $75 \%$ of agricultural assets during market gardening seasons in different regions of the study area. At the household level, onion cultivation is an important source of income and contributes to food and income security for producers. The onion is often the biggest source of cash income and helps to meet the needs of families. At Grand-Popo, as in all the investigated cities (Cotonou, Seme-Kpodji), deferred selling garden products, particularly onion is a powerful lever to support the food security of urban populations. As an activity of counter-season, onion belts allow producers not only to self-employed, to ensure household food security but also to receive significant revenue.

$98 \%$ of surveyed producers recognized that onion production has resulted in many changes in their socio-economic life. In general, improving purchasing power has had a positive impact on food security, education and health situation of farmers. The onion income often also generates new income-generating activities such as petty trading, farming and others. Culturally, onion helps to prepare for marriage or pilgrimage to Mecca. Woman A and Man B two onion producers of Grand Popo and Cotonou asserted: 'Onion production is very important to us. With this production I am more and more autonomous. I depend less on my husband. I don't expect him anymore before buying coal or kitchen utensils. I do all my small expenses through this production income and I can even pay my tontine which was very difficult for me when I was not market gardner' (A).'Onion is very profitable. I produce a lot of vegetables but little counter-season onion i produce, I can invest in my livestock and it is the same money that allow me paying my three children's scholar fees each year' (B).

\section{Importance for input suppliers and other service providers}

To carry out their activities, onion producers have much contact with a range of actors that are upstream in the value chain. Producers purchase pumps and pipes, gasoline, seeds, plows and small equipment, fertilizers and pesticides. Then, there is all kinds of economic relations between producers and suppliers, including the informal credit provision. The majority of the production costs regarding labor. Indeed, the onion sector creates many jobs, often for the poor. There is a redistribution of income from large producers to small producers, landless people in rural exodus through the agricultural labor. In most cases, producers raise funds to run production without financial institutions credit. Man $\mathrm{C}$ a Cotonou seed seller confirms these observations through these words:

'In general market garden production allows us seed sellers to us to quickly sell our products in the city. Most of the time, people come to take the seeds of garden crops like onion and tomato. Many people feed through production. Carriers, agricultural equipment vendors, laborers...' '(C)

\section{Health and nutritional importance for producers-self consumer}

Some market gardeners (6\%) produce the onion just for its nutritional and health importance. For these producers, onion is a valuable culture that they not only produce for sale but also and especially for its therapeutic properties, organoleptic qualities and anti-erosive effect. Three onion self-consumers Men D, E and Woman F justify the importance of the Niger's purple gold in their diet and their health situations.

'The onion gives the taste and flavor. You can prepare a good sauce without putting a little onion. It is sometimes used to garnish the food or mitigate the effect of spicy chili' (D)

'The onion comes in many herbal tea in traditional therapies. When crushed with other products such as garlic, Goussi and others that can heal digestive problems, cancer, liver, rheumatism. It also helps to regulate menstruation cycle of women. My grandfather suffered from high blood pressure but with the adequate consumption of onions, it's much better for a while '(E)

'The onion can be used in all forms: raw for salads, for example, cooked for frying or sauce, cut, beads, rapped or crushed. Onion juice can treat skin acne and provides a smooth and beautiful skin, as well as for hair growth and maintenance, colds, coughs, to sexual arousal' (F). Figure 3 presents the advantages of onion production in southern Benin. 


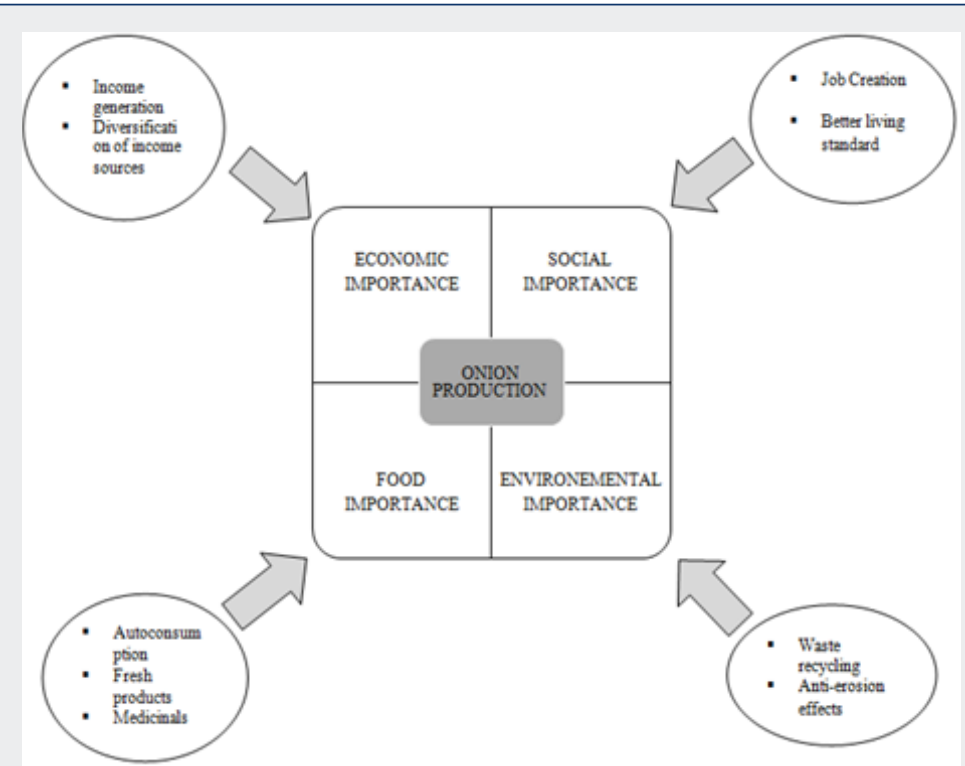

Figure 3: Importance of onion production in southern Benin.

Source: Results of investigation, 2018.

\section{Obstacles and expectations of onion producers in south benin}

Table 8: Constraints of onion production and relevance of these constraints by producers.

\begin{tabular}{|c|c|c|c|c|c|}
\hline $\begin{array}{l}\text { Constraints } \\
\text { categories }\end{array}$ & $\begin{array}{l}\text { Fréquency per } \\
\text { catégorie }(\%)\end{array}$ & $\begin{array}{c}\text { Relevance of } \\
\text { the category } \\
\text { constraints }(/ 10)\end{array}$ & $\begin{array}{c}\text { The most important constraints by } \\
\text { category }\end{array}$ & $\begin{array}{l}\text { Fréquency per } \\
\text { constraints }(\%)\end{array}$ & $\begin{array}{l}\text { Relevance of the } \\
\text { constraints }(/ 10)\end{array}$ \\
\hline \multirow{12}{*}{$\begin{array}{l}\text { Constraints directly } \\
\text { related to the } \\
\text { production }\end{array}$} & \multirow{12}{*}{$66,84 \%$} & \multirow{12}{*}{6,33} & $\begin{array}{c}\text { Lesser quality of the local variety (the } \\
\text { Dendi onion) which rots faster than those } \\
\text { imported }\end{array}$ & $73 \%$ & 6 \\
\hline & & & Rot of onion root and bulbs & $80 \%$ & 8 \\
\hline & & & $\begin{array}{l}\text { Lack of specific inputs for vegetable } \\
\text { (onion) }\end{array}$ & $95 \%$ & 8 \\
\hline & & & $\begin{array}{l}\text { Low mechanization of agricultural } \\
\text { exploitations }\end{array}$ & $60 \%$ & 4 \\
\hline & & & $\begin{array}{l}\text { Low or non-availability of mineral } \\
\text { fertilizers }\end{array}$ & $35 \%$ & 6 \\
\hline & & & $\begin{array}{l}\text { Strong parasite pressure, not control } \\
\text { pests and vegetation in stock }\end{array}$ & $82 \%$ & 7 \\
\hline & & & $\begin{array}{l}\text { yet extensive production system and low } \\
\text { yields Poor weed control }\end{array}$ & $77 \%$ & 7 \\
\hline & & & Low control of grass cover & $43 \%$ & 5 \\
\hline & & & $\begin{array}{l}\text { Germinal low quality and power of } \\
\text { farmers' seeds }\end{array}$ & $71 \%$ & 7 \\
\hline & & & $\begin{array}{l}\text { Weak improved technical mastery of seed } \\
\text { production by farmers }\end{array}$ & $54 \%$ & 5 \\
\hline & & & $\begin{array}{c}\text { Flooding of onion lockers particular by } \\
\text { Portulaca oleracea, Portulac at quadrifida } \\
\text { and Cyperus sp. }\end{array}$ & $48 \%$ & 6 \\
\hline & & & Low technical capacity of producers & $84 \%$ & 7 \\
\hline $\begin{array}{l}\text { Conservation } \\
\text { constraints }\end{array}$ & $33,36 \%$ & 6 & $\begin{array}{c}\text { the lack of appropriate technology for } \\
\text { conservation in large quantities over a } \\
\text { long period }\end{array}$ & $33,3 \%$ & 6 \\
\hline $\begin{array}{l}\text { The marketing } \\
\text { Constraints }\end{array}$ & $44,6 \%$ & 5 & $\begin{array}{l}\text { road harassment suffered by traders } \\
\text { from security and control guards (police, } \\
\text { gendarmes, ...) }\end{array}$ & $44,6 \%$ & 5 \\
\hline
\end{tabular}




\begin{tabular}{|c|c|c|c|c|c|}
\hline \multirow[t]{2}{*}{ Financial constraints } & \multirow[t]{2}{*}{$71,81 \%$} & \multirow[t]{2}{*}{7} & $\begin{array}{l}\text { The cost of Galmi seed and expenses } \\
\text { related to irrigation are as many } \\
\text { handicaps that small producers are not } \\
\text { able to overcome easily. }\end{array}$ & $54,14 \%$ & 6 \\
\hline & & & The difficult access to credit & $89,5 \%$ & 8 \\
\hline \multirow{4}{*}{$\begin{array}{l}\text { Organizational } \\
\text { constraints }\end{array}$} & \multirow{4}{*}{$61,50 \%$} & \multirow{4}{*}{6,5} & $\begin{array}{l}\text { the absence of a policy oriented towards } \\
\text { the strengthening of national production }\end{array}$ & $62,8 \%$ & 5 \\
\hline & & & $\begin{array}{l}\text { poor organization of the onion sector in } \\
\text { Benin }\end{array}$ & $65,4 \%$ & 7 \\
\hline & & & $\begin{array}{l}\text { The lack of organization of market } \\
\text { gardeners in general }\end{array}$ & $70,6 \%$ & 8 \\
\hline & & & $\begin{array}{l}\text { The bad administrative and financial } \\
\text { management of producer's groups }\end{array}$ & $47,2 \%$ & 6 \\
\hline \multirow{2}{*}{ Land constraints } & \multirow{2}{*}{$66 \%$} & \multirow{2}{*}{7,5} & $\begin{array}{l}\text { The Overgrazing and the straying of } \\
\text { ruminants (cattle, sheep, goats) }\end{array}$ & $37 \%$ & 6 \\
\hline & & & Deforestation and soil degradation & $83 \%$ & 9 \\
\hline \multirow[t]{2}{*}{ Material constraints } & \multirow[t]{2}{*}{$73 \%$} & \multirow[t]{2}{*}{6} & $\begin{array}{l}\text { The harvest difficult evacuation due to } \\
\text { the degradation of most of the tracks }\end{array}$ & $76 \%$ & 7 \\
\hline & & & Repeated failures of pumps & $70 \%$ & 5 \\
\hline \multirow{3}{*}{$\begin{array}{l}\text { Institutional } \\
\text { constraints }\end{array}$} & \multirow{3}{*}{$91,33 \%$} & \multirow{3}{*}{7} & The lack of training for producers & $82 \%$ & 6 \\
\hline & & & $\begin{array}{l}\text { Low involvement of technical support } \\
\text { services }\end{array}$ & $98 \%$ & 8 \\
\hline & & & $\begin{array}{l}\text { Low provision of local services for the } \\
\text { supply and distribution of specific inputs }\end{array}$ & $94 \%$ & 7 \\
\hline \multirow[t]{2}{*}{ Natural constraints } & \multirow[t]{2}{*}{$77 \%$} & \multirow[t]{2}{*}{7,5} & $\begin{array}{l}\text { The delay and the poor distribution of } \\
\text { rainfall in time and space }\end{array}$ & $71 \%$ & 7 \\
\hline & & & shortening the rainfall cycle & $83 \%$ & 8 \\
\hline
\end{tabular}

Source: Results of investigation, 2018.

Onion production despite the many benefits that it brings to market gardeners, is facing various difficulties. Analysis of the Table 8 shows that the major constraints identified in onion production in southern Benin are institutional organizational, financial, land orders, and those directly related to production. The market gardeners interviewed affirmed that these constraints were also those for which it was essential that one find solutions. Among the most relevant constraints mentioned by farmers are: the lack of specific inputs for vegetable (onion), strong parasite pressure not control pests and vegetation in stock, the still extensive production system and low yields, low technical capacity of producers, difficult access to credit, poor organization of the onion sector in Benin, the lack of organization of market gardeners in general, deforestation and soil impoverishment, difficult harvest evacuation due to the degradation of most of the tracks, the low involvement of technical extension services, low supply of local services for the supply and distribution of specific inputs, lack of arable land, delay and poor distribution of rainfall in time and space and finally shortening the rainfall cycle.

These results are in the same direction as those obtained by Gotoechan-Hodonou [38] in northern Benin, attic of the onion production. Baco [31] also identified similar constraints in their studies in the field of seed production. The context of the difficulties faced by onion farmers in southern Benin is similar to the case of Niger where the constraints identified were the poor quality and availability of inputs and equipment, problems of access to certified seeds, low financial capacity producers, poor access and insufficient agricultural credit, poor mastery of production techniques, a lack of modern storage infrastructure and huge losses in stock, the traditional character of the transformation, the lack of appropriate packaging the variability of the weight of the bag, the existence of different methods of fixing and price volatility, weak infrastructure and road harassment [39], market saturation after the third cycle of production, the lack of regulatory mechanism supply and demand and competition from foreign imports in the sub-region39. However, among the identified constraints, are institutional, organizational and financial coming to the forefront. It is therefore imperative that the public and private agricultural institutions orient their policies in a process of facilitation and development of onion production in Benin. Despite the efforts, the producers of South Benin still face enormous difficulties that significantly hamper production. Producers have issued many approaches that could improve production conditions and therefore their living conditions. The most important approaches proposed by the producers were related to the main constraints mentioned. Man X and Woman Y, two onion producers argued about it, respectively:

'We know that we are in cities, so with regard to the land is lacking but we did not complain too much. But there are things the government can do to make our job easier. For example, they can create agricultural credit services for onion producers, they can put 
us in group; can also be formed on the most effective technologies of production. It is necessary that the state helps.' (X)

'It is difficult to produce in cities, but we mostly need help. We receive no government support. Nobody supervises us, we cope alone. We would like the state begins to take us for help. The state focuses on cotton or cashew forgetting that gardening provides food security especially those urban populations. I don't know if they know but especially gardening onion production is more profitable than cotton. I have produced cotton in the North before coming south for work. But finally I gave myself to the production of onion because it gives me more revenue especially against season. I strongly urge agricultural institutions to find us improved varieties of onion seeds, financing for irrigation and the launch of activities, organizing into cooperatives and especially we organize training courses.' (Y)

\section{Conclusion}

Onion production is a very important sector which may be considered not only to ensure food security of urban populations but also to improve the living conditions of the producers. This production proves very financially profitable for producers in southern Benin. In addition to its financial performance, it also impacts on social, health, nutritional and environmental producers living. It allows a large number of producers and a considerable number of actors as service providers to have substantial income. However, it would be interesting for agricultural policies to develop actions to limit constraints of this production in southern Benin.

\section{References}

1. Miassi YES, Dossa KF (2018) Socio-Economic determinants of the adoption of agricultural contracts: Case of cashew farmers in NorthEastern Benin. Int J Progress Sci Technol 6(2): 243-250.

2. Dossa KF, Miassi YES (2018) Facteurs Socio-Economiques influençant l'adoption de coton biologique au Nord-Est du Bénin : Cas de la commune de Kandi. Int J Progress Sci Technol 6(2): 577-584.

3. AVRDC (The World Vegetable Center, Taiwan) (2004) Global horticulture: Now is the time for action. AVRDC Publication In: Shanhua, Taiwan, AVRDC-The World Vegetable Center, pp. 1-29.

4. Dennings G (2007) Agriculture leads to the MDGs rural development in Africa. UN Chronicle, 44(4): 6.

5. Sanginga N (2010) Innovations as key to the green revolution in Africa: Exploring the scientific facts. Nutrient Cycling in Agroecosystems 88(1): $1-2$.

6. Pretty J, Toulmin C, Williams S (2011) Sustainable intensification in African agriculture. Int J Agric Sust 9(1): 5-24.

7. Robinson LW, Ericksen PJ, Chesterman S, Worden JS (2015) Sustainable intensification in drylands: What resilience and vulnerability can tell us. Agric Syst 7(135): 133-140.

8. United Nations Habitat (2015) The state of African cities, 2014: Reimagining sustainable urban transitions. Kenya [Sl]: United Nations Publications, USA, pp.200.

9. Godfray HCJ, Beddington JR, Crute IR, Haddad L, Lawrence D, et al. (2010) Food security: The challenge of feeding 9 billion people. Int J Sci 327(5967): 812-818
10. Lele U, Pretty J, Terry E, Trigo E (2010) Transforming agricultural research for development. Global author team, for Global Conference on Agricultural Research (GCARD), Montpeiller, France, pp. 36-48.

11. Nchanji EB, Bellwood Howard I, Schareika N, Chagomoka T, Schlesinger J, et al. (2017) Assessing the sustainability of vegetable production practices in northern Ghana. Int J Agric Sust 15(3): 321-337.

12. Mougeot L (1995) L'agriculture urbaine en Afrique d'un point de vue mondial. In: Faire campagne en ville: L'agriculture urbaine en Afrique de l'Est. Ottawa: CRDI, pp. 77-84.

13. Mougeot L (2000) Urban agriculture: Definition, presence, potentials and risks. In Bakker N, Dubbeling M, Guendel S, Sabel Koschella U, De Zeeuw H (eds); Growing cities, growing food: Urban agriculture on the policy agenda. Feldafing: DES, p. 1-42.

14. Moustier P, Fall A (2004) Les dynamiques de l'agriculture urbaine: caractèraction et évaluation. In : Smith OB, Moustier P, Mougeot LJA, Fall SA (eds); Développement durable de l'agriculture urbaine en Afrique francophone: Enjeux, concepts et méthodes. Montpellier: CIRAD/CRDI, pp. 23-43.

15.Van Veenhuizen $\mathrm{R}$ (2006) Cities farming for the future. In: Van Veenhuizen R, Cities farming for the future : Urban agriculture for green and productive cities, Silang: RUAF Foundation, International Institute of Rural Reconstruction; International Development Research Centre, pp. 1-17.

16. Bon H, Parrot L, Moustier P (2010) Sustainable urban agriculture in developing countries. Agronomy for Sustainable Development 30(1): 21-32.

17. Hossain M, Ahmed M, Ehsanul Haq M, Shefat Al Maruf M, Nur e Nabi M, et al. (2017) Quality Seed of Onion: Effect of Micro and Macronutrients. Annual Research \& Review in Biology 20(6): 1-11.

18. Liguori L, Califano R, Albanese D, Raimo F, Crescitelli A, et al. (2017) Chemical composition and antioxidant properties of five white onion (Allium cepa L) landraces. Hindawi Journal of Food Quality, p. 1-9.

19. Banjongsinsiria P, Noojuya N, Lekhavata S, Phatvejb W, Sematongb T, et al. (2017) The Onion extract fortified into herbal tea drink and its properties. Food and Technology, Integration for ASEAN economic community sustainable development proceedings of the $15^{\text {th }}$ ASEAN Conference on Food Science and Technology, Ho Chi Minh City, Vietnam, p. 1-6.

20. Pareek S, Sagar NA, Sharma S, Kumar V (2017) Onion (Allium cepa L). p. 1-14.

21. FAO (2012) World onion production, Food and Agriculture Organization of the United Nations. Rome, Italy.

22. FAO (2018) Food and Agriculture Organization of the United Nations. Rome, Italy p. 57

23. Dédéwanou KCB (2010) Analysis of the adoption of the Integrated Management of Soil Fertility (GFIS) and Pests (GIR) of the WACIP program by the cotton producers of Banikora commune in northern Benin, (Unpublished Master dissertation), thesis for the Agronomy Engineer diploma, Faculty of Agronomy, Parakou, Bénin.

24. Adégbola PY, Akplogan F, Singbo A (2004) Market farms of Grand-Popo. pp. 1-28.

25. Bockel L, Tallec F (2005) The financial analysis sector approach. pp. $1-44$.

26. Tovignan S, Hinvi J, Glin LC, Sodjinou E, Bonou Zin R, et al. (2014) Determinants of the profitability of organic cotton production in Benin. 3rd West African Conference on Organic Agriculture from 27 to 29 August 2014, Cotonou, Benin.

27. Allagbe CM, Adegbola PY, Ahoyo Adjovi NR, Komlan Ahihou CM, Crinot GFD, et al. (2014) Study funded by the Multinational Project Supporting the Cotton-Textile Sector in the four countries of the Sectorial Initiative 
on Cotton (PAFICOT) -Benin. Technical Implementation Report of INRAB pp. $1-45$.

28. Bethesda MD (2008) Subregional assessment of the onion/shallot value chain in West Africa. ATP Project, Onion/West Africa Study, RECA Niger p. 1-5.

29. Cathala M, Woin N, Essang T (2003) Onion, a booming production in North Cameroon. 475 in Jamin JY, Seiny Boukar L, Floret C, African savannahs: changing spaces, 476 actors face new challenges. Montpellier: CIRAD.

30. Tarchiani V, Robbiati G, Salifou MR (2013) Onion sectors in West Africa: comparative study of the Nigerien and Beninese sectors. Cahiers Agricultures 22(2): 112-123.

31. Baco MN, Bello S, Assogba Komlan F (2005) Socio-economic study of the production and marketing of onion in Alibori. Bul Rech Agro Ben 47(6): 26-37.

32. Affomasse D (2001) Study of the constraints and potentialities of the post-harvest system of the onion. Post-harvest CRRD 2001, CotonouBenin pp. 1-20.

33. Saizonou J (2006) Onion Forum of Malanville. Sanitize the market access roads of 528 commercializations. Agriculture 76(5): 1-29.

34. Boluvi GM (2004) Malanville Gaya: trading post and corridor of speculation (country-472 border of the informal). Club Sahel/OECD 473, Paris.
35. MAHRH (2007) Analysis of the market gardening sector in Burkina Faso. Ouagadougou, Burkina Faso pp. 1-127.

36. Fanou L (2008) Financial and economic profitability of market gardening systems in South Benin: An application of the Policy Analysis Matrix. Downloaded from online thesis, thesis for agronomy engineer diploma, UAC, Benin pp. 1-130.

37. Labiyi IA, Ayédèguè L, Yabi AJ (2013) Analysis of the economic efficiency of resource allocation in soybean production in Benin. Laboratory of Analysis and Research on Economic and Social Dynamics (LARDES) pp. $1-19$

38. Gotoechan Hodonou H, Savi AD (2001) Diagnostic study on onion production in the department of Alibori. In Act of the North Scientific Workshop (Edn), Parakou, Benin, pp. 109-119.

39. CSA (Collectif Stratégies Alimentaires) (2001) The onion sector of Niger: Analysis of the capacities of small family farmers and identification of value-added strategies in the context of the construction of local markets. Document produced with the contribution of Elena Temneanu and produced with the co-financing of the European Commission and the Directorate-General for Development Cooperation (DGCD - Belgium). Brussels, CSA Belgium pp. 67.

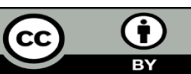

This work is licensed under Creative Commons Attribution 4.0 License

To Submit Your Article Click Here:

Submit Article

DOI: $10.32474 /$ CIACR.2018.03.000159 